Article

\title{
Digital Inclusion Across the Americas and the Caribbean
}

\author{
Laura Robinson $^{1}$, Jeremy Schulz ${ }^{2}$, , Matías Dodel ${ }^{3}$, Teresa Correa ${ }^{4}$, Eduardo Villanueva-Mansilla ${ }^{5}$, \\ Sayonara Leal ${ }^{6}$, Claudia Magallanes-Blanco ${ }^{7}$, Leandro Rodriguez-Medina ${ }^{8}$, Hopeton S. Dunn ${ }^{9}$, \\ Lloyd Levine ${ }^{10}$, Rob McMahon ${ }^{11}$ and Aneka Khilnani ${ }^{12}$ \\ ${ }^{1}$ Department of Sociology, Santa Clara University, Santa Clara, CA 95053, USA; E-Mail: laura@laurarobinson.org \\ 2 ISSI-Institute for the Study of Societal Issues, University of California Berkeley, Berkeley, CA 94720, USA; \\ E-Mail: jmschulz@berkeley.edu \\ ${ }^{3}$ Department of Communications, Catholic University of Uruguay, 11600 Montevideo, Uruguay; \\ E-Mail: matias.dodel@ucu.edu.uy \\ ${ }^{4}$ School of Communication, Diego Portales University, 8370067 Santiago, Chile; E-Mail: teresa.correa@udp.cl \\ ${ }^{5}$ Department of Communications, Pontifical Catholic University of Peru, 15088 Lima, Peru; E-Mail: evillan@pucp.pe \\ ${ }^{6}$ Department of Sociology, University of Brasília, 70843-120 Brasilia, Brazil; E-Mail: sayonaraleal@uol.com.br \\ 7 Department of Humanities, Ibero-American University Puebla, 72810 San Andrés Cholula, Mexico; \\ E-Mail: claudia.magallanes@iberopuebla.mx \\ ${ }^{8}$ Department of International Relations and Political Science, University of the Americas Puebla, 72810 San Andrés Cholula, \\ Mexico; E-Mail: leandro.rodriguez@udlap.mx \\ ${ }^{9}$ Department of Media Studies, University of Botswana, Gaborone, Botswana; E-Mail: hopeton.dunn@mopipi.ub.bw \\ ${ }^{10}$ School of Public Policy, University of California at Riverside, Riverside, CA 92521, USA; E-Mail: Iloydlevine@outlook.com \\ 11 Faculty of Arts, University of Alberta, Edmonton, AB T6G 2R3, Canada; E-Mail: rob.mcmahon@ualberta.ca \\ 12 School of Medicine and Health Sciences, George Washington University, Washington, DC 20052, USA; \\ E-Mail: aneka@gwu.edu
}

* Corresponding author

Submitted: 11 November 2019 | Accepted: 22 April 2020 | Published: 14 May 2020

\begin{abstract}
This research brings together scholarship across the Americas and Caribbean to examine digital inclusion initiatives in the following countries: Uruguay, Chile, Peru, Brazil, Mexico, Cuba, Jamaica, the United States, and Canada. Across the cases, several themes emerge that offer important indicators for future digital inclusion initiatives. First, public policy can effectively reduce access gaps when it addresses the trifecta of network, device, and skill provision. Second, this triple-crown of public policy is highly effective for longitudinal effect when implemented early via educational institutions. Third, ruralurban digital inequality is resistant to change such that rural populations benefit less from policy initiatives than their urban counterparts. Fourth, digital inclusion in rural areas and among marginalized populations is most effective when cocreated with communities to ensure community investment, participation, and control. Fifth, stay-at-home orders during the COVID-19 pandemic are rapidly increasing our dependence on digital technologies, making digital inclusion more important than ever for education and rural communities. We therefore close the article with discussion of how the COVID-19 pandemic is amplifying digital disadvantage and exclusion across the Americas, the Caribbean, and the globe.
\end{abstract}

\section{Keywords}

Caribbean; COVID-19; digital divide; digital inclusion; digital inequalities; Latin America; North America; pandemic

\section{Issue}

This article is part of the issue "Digital Inclusion Across the Globe: What Is Being Done to Tackle Digital Inequities?" edited by Bianca C. Reisdorf (University of North Carolina at Charlotte, USA) and Colin Rhinesmith (Simmons University, USA).

(C) 2020 by the authors; licensee Cogitatio (Lisbon, Portugal). This article is licensed under a Creative Commons Attribution 4.0 International License (CC BY). 


\section{Introduction: Digital Inclusion across the Americas and Caribbean in Times of Pandemic}

At the time of writing we are in the midst of the COVID-19 global pandemic. Due to lockdown measures across the globe, the pandemic is deepening the plight of the digitally under-resourced and excluded. In response to stayat-home orders, the digitally resourced are moving their communications, work, healthcare, and relationships online. Yet the digitally disadvantaged must shelter in place without opportunities to maintain employment and income through telework from home or continue studies through e-education. They do not have access to digital social networks to mitigate physical and social isolation; they also lack access to digital information seeking for public health and telemedicine. The pandemic has thus brought to a head the need for digital inclusion for all.

To offer a panorama of key initiatives for digital inclusion, this research brings together digital inequality scholars from across the Americas and Caribbean. We take a comparative perspective to probe national initiatives from Uruguay, Chile, Peru, Brazil, Mexico, Cuba, Jamaica, the United States, and Canada. Across the national cases, several themes emerge. First, public policy can effectively reduce access gaps when it addresses the trifecta of network, device, and skill provision. Second, this triple-crown of public policy is also most effective over the long term when implemented early via education so that children "grow up digital" (Tapscott, 2008). Third, rural-urban digital inequality is resistant to change such that rural populations benefit less from policy initiatives than their urban counterparts. Fourth, digital inclusion in rural areas and among marginalized populations is most effective when co-created with communities to ensure community investment, participation, and control. Fifth, stay-at-home orders during the COVID-19 pandemic are rapidly increasing our dependence on digital technologies, making digital inclusion more important than ever for education and rural communities.

From these findings, we see the urgent need for short-and long-term digital inclusion strategies. To immediately respond to the pandemic, emergency policy measures should convert internet access into a subsidized public utility. In addition, other commercially driven policies (such as data caps) should be re-evaluated to decrease the burden of connectivity costs on marginalized populations. In addition to network access, policy measures must address device gaps, as well as skill inequalities through training and education.

Long-term, initiatives should focus on hard-to-reach, remote, and rural communities outside urban cores while meeting social, economic, and political needs. Researchers and policy makers seeking to meet digital needs must engage in initiatives that are co-created with communities to ensure that they develop and deliver digital resources in ways that respect their diversely situated contexts (McMahon, the First Mile Connectivity Consortium, \& the Piikani Cultural and Digital Literacy
Camp Project Team, 2020). If these kinds of endogenous development strategies are achieved, future digital inclusion strategies will not only meet material needs but also contribute to efforts to mitigate feelings of social and/or territorial isolation generated by insufficient access to digital resources and education.

\section{Digital Inclusion in Uruguay}

Uruguay is a small $\left(176,000 \mathrm{~km}^{2}, 3.4\right.$ million inhabitants) and predominantly urban (95\%) country (United Nations, 2019). Of the countries in South America, Uruguay has one of the lowest levels of income inequality and poverty but still lags compared to developed economies. Uruguay also has a high penetration of digital technologies, political stability, and welfare state development (Nathan, Pardo, \& Cabella, 2016). This tradition of welfare provision is reflected in the country's digital inclusion strategy. Since the 2000s the government began to implement innovative policies on the national level to successfully reduce digital disparities. Two flagship initiatives stand out: Plan Ceibal and Plan Ibirapitá (Clastornik, Dornel, \& Parra 2016).

Plan Ceibal was created in 2006 and counts as one of the most successful country-level "One Laptop Per Child" initiatives in the world. Ceibal's project was successful in great part because it was developed to be far more than just a program providing a laptop. It started as a 1-to-1 device provision initiative, allocating devices to all students and teachers in the public education system. Further, Ceibal also provided high-quality connectivity to schools, created an ecosystem of free educational software and contents, and distributed new pedagogical practices to complement them (Plan Ceibal, 2017).

Among several positive outcomes, Ceibal universalized PC and internet use through the Uruguayan Kids program that shrank differences in household PC access according to income and locality (Dodel, 2015; Dodel, Kweksilber, Aguirre, \& Méndez, 2018). Moreover, by supplying computers to children and teachers, as well as providing free access to educational services and software, Ceibal's role has been critical during the COVID-19 quarantine to ensure the continuation of public and private education even under lockdown during which schools have shut down for 2020 (Plan Ceibal, 2020). However, as the enrollment in Ceibal's new pedagogy initiatives is non-compulsory, their effects depend on the teachers' willingness to adopt them, partially replicating preexisting educational inequalities (Trucco \& Espejo, 2013).

Plan Ibirapitá in many ways replicates the success of Ceibal among seniors. Ibirapitá was created in 2015 to promote digital inclusion among older adults (Plan Ibirapitá, 2017). Ibirapitá provided tablets with user-friendly front-end interfaces and services to socioeconomically disadvantaged older adults. Ibirapitá also provided free workshops to learn how to operate the devices, thus reducing usage barriers related to skills. Providing both devices and skills training ensured the suc- 
cess of the program by tackling the population's lack of digital experience (Sunkel \& Ullmann, 2019).

While the Ibirapitá program did increase internet usage among older Uruguayans (Sunkel \& Ullmann, 2019), the program's scope was limited to low SES pensioners. Unlike Ceibal, which was universally available, Ibirapitá focused only on a certain class of lower-income retirees. Neither non-retirees (many of whom are economically disadvantaged) nor older adults with higher incomes were beneficiaries of the program. There were two other challenges to the program's success, even within its target population (Plan Ibirapitá, 2017). First, retirees could only access the program's workshops at remote locations and delivery points. Second, the workshops could not address pre-existing levels of technophobia that may have precluded participation.

Nonetheless, even with their limitations, Ceibal, Ibirapitá, and complementary infrastructure policies were instrumental in expanding digital inclusion among Uruguayans. Along with digital policies relating to e-government and electronic health services (Clastornik et al., 2016), Uruguayan public policies have ensured higher levels of digital well-being among many. Finally, Ceibal and Ibirapitá have become solid pillars of the Uruguayan welfare state's digital inclusion policies during the 2020 pandemic. Their success has been further enhanced by policy measures to provide free home internet access with the removal of data caps during the COVID-19 quarantine.

\section{Digital Inclusion in Chile}

Chile has long-standing policies tackling digital inequality through expanding internet access and adoption (Kleine, 2013). Nationally, household internet access (either through fixed or mobile broadband) grew from $60.4 \%$ in 2012 to $87.4 \%$ in 2017 (Subsecretaría de
Telecomunicaciones, 2019). The urban-rural gap has significantly decreased from $30.6 \%$ in 2012 (64.1\% vs. $33.5 \%$ ) to only $12.4 \%$ in 2017 (89.1\% vs. $76.7 \%)$. Most of this growth has been driven by mobile broadband connections and smartphones. With 17 million inhabitants, Chile has a diverse geography: vast deserts in the north, islands, fjords, and rushing rivers in the south, and the Andes mountain range that stretches the length of the country. These geographic characteristics represent distinct obstacles to providing internet access infrastructure to rural areas. Even with these limitations, Chile has made notable strides in internet adoption, with a $63 \%$ rise in internet adoption between 2005 and 2016 (Figure 1).

Managed by the Undersecretary of Telecommunication, the Telecommunication Development Fund policy initiative addressed the urban-rural digital divide by expanding infrastructure in rural areas. Given Chile's geographical challenges, the fund incentivized the expansion of internet infrastructure to areas that were less financially attractive to telecommunication companies. The plan subsidized providers to connect isolated areas with low SES populations at or below the same cost as the nearest urban area. Although coverage could be provided through different forms of connectivity (including fixed, fiber-optic, or mobile broadband), the vast majority of the new connections relied on mobile-broadband infrastructure. Through the program "All Chile Connected," this fund has extended 3G/4G mobile connection to more than 2000 vulnerable areas since 2010. As a result, mobile internet connection and geographic coverage has significantly increased; the urban-rural gap has decreased in the past five years.

However, provision of infrastructure alone is insufficient. Despite the expansion of mobile internet coverage, skills gaps and lack of awareness remain challenges in remote villages. A face-to-face random survey in several isolated communities served by the Telecommunication

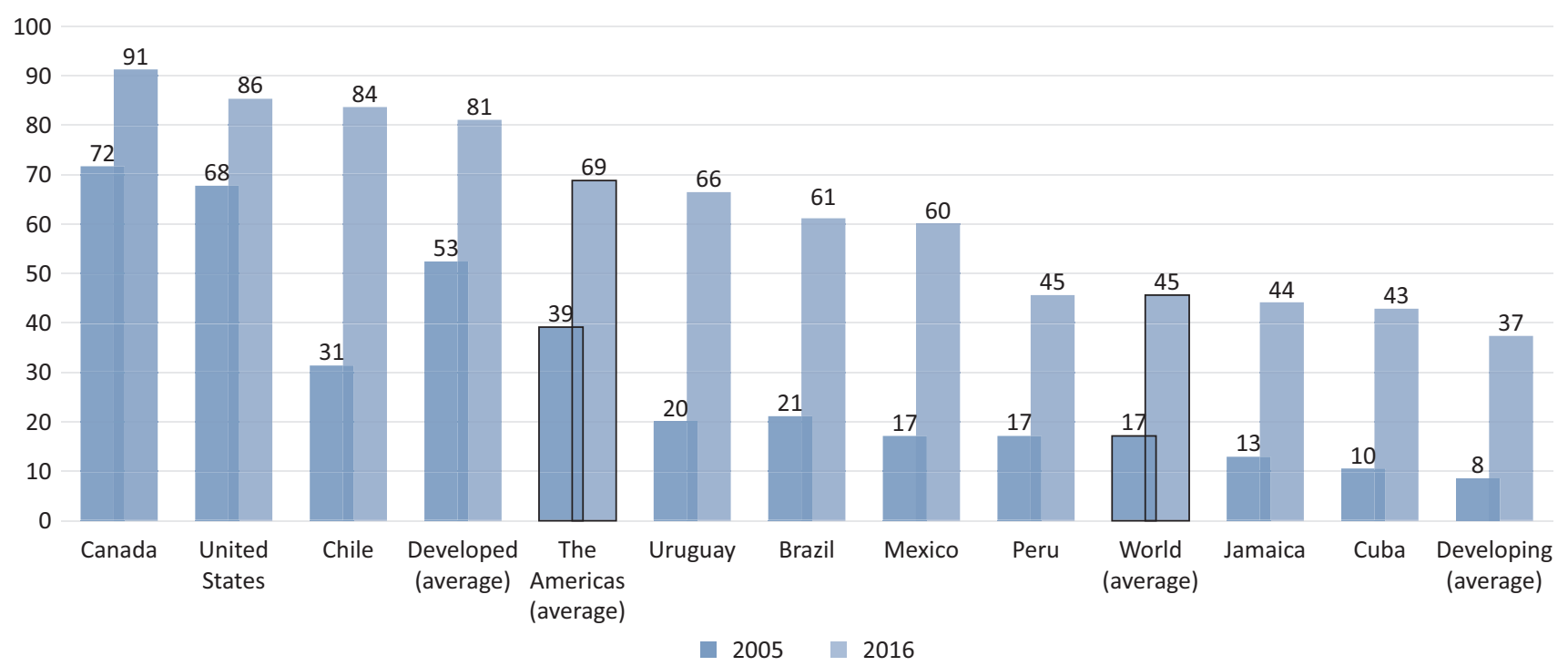

Figure 1. Individuals using the internet (percentages), 2005-2016. Assembled by author Matias Dodel with data from International Telecommunications Union (ITU, 2019a). 
Development Fund revealed that only $37 \%$ of people used the internet (Correa, Pavez, \& Contreras, 2017). This result is in line with findings in other Latin American countries where there is a gap between higher coverage and lower demand (Galperín, 2017). Findings revealed several causes for lower demand among rural populations, including insufficient awareness of opportunities and education regarding technologies' purpose. Further, lacking skills, residents were hesitant to bring unknown technologies into their close-knit communities. Insufficient skills training, as well as private or public outreach regarding potential benefits, undermined the potential success of infrastructure provision.

In addition, the strong policy emphasis on mobile coverage has led to a significant increase in mobile-only users, particularly through smartphones (Correa, Pavez, \& Contreras, 2018). Although it represents an affordable and easier-to-use mode of access, mobile-only use is associated with lower levels of digital skills and fewer types of internet uses (Napoli \& Obar, 2014). The limitations of mobile-only use on smartphones have been particularly evident in the era of COVID-19 among students. During the pandemic, those students required to connect online for their studies were at a distinct disadvantage when limited to connectivity via smartphones.

Therefore, despite the success of policies to increase coverage and expand infrastructure, additional work is needed to address the societal aspects of digital inclusion. More effective work can be done when government agencies join forces with the communities they serve and respond to communities' own assessment of their needs and particular contexts. Taken in this direction, future policy should seek to build infrastructure tailored to communities' needs and complement the infrastructure with skill learning and outreach.

\section{Digital Inclusion in Peru}

In Peru, rural populations are the most exposed to structural poverty for several long-standing reasons. Rural populations are less likely to enjoy economic opportunities, as well as access to education and health services. Due to their status as linguistic minorities speaking Indigenous languages instead of Spanish (the language used by the Peruvian state for its services), rural populations in Peru have also long been culturally marginalized.

Because of the difficult geographical terrain and the poverty of the rural population in Peru, market actors have not made investments to build the necessary infrastructure to serve populations with very limited purchasing power. The Peruvian government has therefore subsidized the building of infrastructure in difficult terrain where distances and conditions, from the high Andean plains to Amazonian river basins, pose substantial barriers and where the rural population cannot afford commercial services.

Using technological solutions to compensate for the absence of services is one of the tenets of ICTD thinking.
Tackling the first hurdle of connectivity, Peru's Programa Nacional de Telecomunicaciones employed compensation and subsidy strategies with funds generated by commercial operators to provide connectivity to rural populations. One such initiative, the Rural Telecommunications Group (GTR in Spanish) carried out by Pontifical Catholic University of Peru (Telecom), in coordination with EHAS Foundation and Hispanic-American Linkage on Health, has accomplished a feat of engineering which makes possible connectivity under very complex and challenging conditions. This achievement has allowed many communities to connect to the internet for the specific purpose of providing e-health services. A variety of projects (Ludeña, Martínez, \& Rendon, 2011; Rey-Moreno et al., 2011) were conducted from 1999 to 2014 under this umbrella. All the projects succeeded in providing connectivity sufficient to enable these services, even in very difficult terrain.

The infrastructure created by these initiatives had to supply not only basic internet connectivity, but also the capabilities necessary for data transmission involved in tele-diagnosis (including stethoscope, microscope, and sonogram data capture in situ) in remote locations. The telemedicine services enabled by this infrastructure allow local medical staff to carry out sophisticated medical interventions with the aid of collaboration with specialists located in other areas. This collaboration is possible because of the user-friendly telemedicine interfaces and low maintenance equipment which local healthcare staff can easily operate with training (Prieto-Egido, Simó-Reigadas, Liñán-Benítez, García-Giganto, \& Martínez-Fernández, 2014).

These successes in the Peruvian context demonstrate technical feasibility and the capacity of the program to bring about desired institutional and societal outcomes that can improve people's lives in measurable ways. GTR projects, while successful in their immediate domain, could not surmount other overwhelming problems that impinge on quality of health services, which lie at the institutional domain (the lack of resources and absence of innovation in health provision at the local level for rural communities) and the societal domain (the actual adoption of best practices by the community being served). This can be attributed to disconnects between technological goals and social development goals, and the necessary connection between the two that institutional change has to produce.

The pandemic, which has led to lockdowns in Peru, makes solving these problems even more urgent and relevant and shows the importance of integrated approaches. Even when connectivity projects are successful, their usefulness for other purposes, like distance and virtual education, is not guaranteed without community buy-in and enhanced awareness of available resources. Under lockdown, telemedicine is not the only service which needs to be provided online. Distance education, for example, may be the one chance for Peruvian children to continue their schooling. These challenges require an inte- 
grated approach comprised of provision of commercial access, efforts to raise awareness of resources, and community involvement to motivate the public to use digital resources-all in times of pandemic and beyond.

\section{Digital Inclusion in Brazil}

The Brazilian case serves as a compelling example of how policies aimed at promoting social solidarity and cohesion in the digital realm may prove insufficient when there is a gap between economic performance and digital inclusion. This divergence has led to the uneven insertion of Brazil into the global information society. While Brazil ranks in the top ten in terms of the size of its economy, in addition to constituting one of the main telecommunications and information technology markets in the Americas (ITU, 2018), it is also one of the top ten countries with the greatest level of economic inequality on the planet (United Nations Development Program, 2016). Roughly a quarter $(26.5 \%)$ of its population currently lives below the official poverty line, according the Brazilian Institute of Geography and Statistics (2018). The inequality gap is especially apparent when we consider the fact that $44 \%$ of Brazilians who do not use the internet are from social classes D and E (the two lowest income categories).

Overall, sixty-seven percent of Brazilian households have access to the internet. However, internet access is not considered to be a public service in Brazil. The 2014 Brazilian Civil Rights Framework 'guarantees' internet access as a right and a vehicle through which to exercise citizenship. However, this formal guarantee is merely pro forma; in practice internet service is supplied by commercial operators who charge high fees. Due to service costs (Brazilian Internet Steering Committee, 2019), only $40 \%$ of economically disadvantaged Brazilians have internet service. Moreover, the device divide still pervades Brazilian society. While Brazilian households are more likely to have cell phones (93\%), television sets (96\%), and radios (62\%), far fewer have a fixed landline telephone (24\%), desktop computers (19\%), laptop computers $(27 \%)$, cable TV (25\%), or tablets (14\%) (ibid).

Despite these disparities, the Brazilian government has broadened access with a number of digital inclusion initiatives. These initiatives were institutionalized through publications and programs such as the Green Book on the Information Society, the Digital Cities Broadband Program, the National Broadband Program, and the Governance Digital Policy Program. Federal programs are based on the distributive model for access, training in the use of ICTs (digital literacy), network infrastructure improvements, free internet access provision in low-SES communities, satellite connectivity for schools and public services, and incentives for the development of free software and subsidized laptops and computers for teachers and students in public schools.

Like Peru and Chile, Brazil must confront challenging terrain that impedes the installation of infrastructure. Submarine cables and satellite coverage are necessary in regions where natural obstacles such as vegetation do not allow optical fiber and infrastructure expansion (ITU, 2018). To meet this need, Brazil has created successful programs providing satellite connections for public schools and tele-centers (public spaces offering free access to the internet) in underserved communities. The National Program of Educational Technology (PROINFO), created by the Ministry of Education in 1997, works with schools in both urban and rural areas to provide computers, digital resources, and educational content; the program is present in $50 \%$ of urban public schools, which also benefit from the School Broadband Program (da Silva, 2018).

The government's Citizens Electronics Service Program (GESAC) provides satellite coverage to 9,327 locations across the country where services through private operators are not available (personal interview, 2019). In 2017, GESAC provided connections to 649,579 students in 2,456 schools located in rural areas. In addition to GESAC, 6,673 youths were trained under the Rural Youth, Computers for Inclusion, and Citizenship Networks Programs. In sum, there are 3,452 municipalities with coverage of this type of network, comprising $62 \%$ of the total of Brazilian municipalities. By 2015, approximately twenty digital inclusion programs were subsidized by the state and managed by various ministries. However, deficiencies in the institutionalization of these policies and failure to maintain consistent dialogue have, in some cases, led to disconnects between government programs that threatened success.

In response to social isolation measures enacted to combat COVID-19, some measures have been adopted by the Brazilian government. The Ministry of Health has invested in public health initiatives via digital devices to inform the population about the disease, campaign for social distancing, and counter fake news related to contamination with applications such as "CoronavirusSUS" (Ministry of Health, 2020). Further, policies have been enacted to ensure that operators expand access to telecommunications services during the pandemic, including increasing fixed broadband speed, providing Wi-Fi networks in public places, and extending deadlines for payment of services (National Telecommunications Agency, 2020). These measures brought on by the pandemic underscore the need for digital inclusion policies to meet social, educational, labor, and health needs.

\section{Digital Inclusion in Mexico}

Mexico as a case study sheds light on a market-driven national policy on telecommunications that does not target the needs of rural or remote populations. Mexican telecommunications policy is market driven and has focused on increasing competition, promoting investment, expanding broadband coverage, and increasing affordability (Rosas \& Ovando, 2018). Networks and devices are provided as commercial services by transnational corporations in major cities and urban areas. In spite of sig- 
nificant increases in the numbers of internet and mobile phone users between 2000 to 2016 (ITU, 2018), digital inclusion remains a challenge for those in rural or remote areas. In response, Indigenous communities and grassroots organizations in Mexico have stepped up to tackle the challenges of digital inclusion that national policy has not addressed and that market actors have neglected.

In 2013, the Constitutional Reform for Telecommunications opened the Mexican telecommunications sector to promote competition and affordability. Successful results included a price decline in the mobile sector, as well as price reductions in international long distance and mobile phone rates. There was also enormous sector growth: 141 new radio broadcasters, a third national TV chain, 33 new free-to-air local TV stations, and the release of the $700 \mathrm{MHz}$ band to build a Shared Wholesale Network (SWN) providing 4G broadband access to at least $85 \%$ of the population of which $12.75 \%$ should live in areas with less than 10,000 inhabitants. (García Requena, 2018; Rosas \& Ovando, 2018). According to the National Pool on Availability and Use of Information Technologies at Households, in 2018 only $40.6 \%$ of rural dwellers used the internet (compared to $73.1 \%$ of urban dwellers) despite the 2013 telecommunications reform and the creation and implementation of the SWN. Rural connectivity gaps are most prevalent in states with the greatest economic challenges such as Guerrero, Oaxaca and Chiapas (Instituto Nacional de Estadística, Geografía e Informática, 2018).

In this context, several communities, based on Indigenous organizational, economic and political systems have created, deployed, and maintained different telecommunications projects operating last-mile networks. Two examples are the community cellular networks in Oaxaca and community intranets. Community cellular networks operate in 14 communities in Oaxaca with coverage in 63 localities where 3500 users are served. Rhizomática created this model, giving rise to what Magallanes-Blanco and Rodriguez-Medina (2016) called the "technical program." Redes por la Diversidad, Equidad y Sustentabilidad A.C. (REDES A.C.) developed the "legal program." Such programs necessitated legal and technical skills for developing networks; their success set precedents that led to legislative reforms including augmented usage of the telecommunications spectrum for social benefit.

They offer a uniquely successful model such as the Telecomunicaciones Indígenas Comunitarias (TIC A.C.) in which the network's member communities provide "technical support, peer-to-peer support and maintenance of their networks. TIC A.C. is a fully licensed, socialIndigenous operator of cellular services" (Baca-Feldman, Bloom, Gómez, \& Huerta, 2018, p. 179). Rather than top-down national policy, rural populations in Mexico rely on Indigenous communities' own initiatives. These networks are a semi-closed and local system of wireless nodes that provide access to locally hosted content. Beginning in 2017 Rhizomática (with the support of REDES A.C. and others) has developed a model of community intranets in four Mexican communities in the states of Chiapas, Nayarit and Oaxaca.

These projects are successful case studies of community-based projects addressing the connectivity gap in rural and remote areas. In times of crises, such as the devastation caused by the 2017 earthquakes in southern Mexico, Indigenous communities responded by producing and sharing digital resources such as podcasts that kept the population informed and attended to the needs of isolated and remote communities. Again, in response to the current COVID-19 pandemic, Indigenous peoples are translating vital information to Indigenous languages and sharing it through the community intranets. While their efforts are admirable and provide a model of success, they cannot be expected to wholly substitute for national policy. The COVID-19 pandemic has made this tension more evident as people in rural or remote areas face the challenges of an online response to the pandemic without adequate digital resources such as Indigenous students left out of online education who now risk losing an academic year or a college semester due to gaps in digital learning.

\section{Digital Inclusion in Cuba}

With a population of almost 12 million people, Cuba offers an important case study in three ways: first, the relevance of geopolitical contexts (in this case, the US-led embargo since 1962) to technology development; second, the contradictions inherent in expanding ICT access under an authoritarian regime resistant to challenges; and third, the contribution of state-led policies to the underutilization of the internet and other ICTs.

Cuba has an outdated infrastructure and low rates of internet penetration due to complex causes including state provision of networks and devices (historically in tandem with countries such as the USSR or Venezuela), as well as the US-led embargo and associated economic limitations. Between 1959 and 2018 there has only been a $7 \%$ increase in telephone penetration (3\% to 10\%). Even in 2008 when ETECSA was finally legally allowed to offer mobile devices, the rates were unaffordable. In 2016, Cuba still had low mobile internet penetration ( $2 \%$ of the population); of these, only $26 \%$ had smartphones (Sharma \& Lucini, 2016). Public internet was accessible only in 2013, and further, was limited to 118 national "navigation points" with slow speeds and prohibitive costs (Bisset Álvarez, Grossi de Carvalho, \& Vidotti, 2015; Elizalde \& Lagarde, 2013). In addition, only $57 \%$ of the population self-identifies as internet users; just over $15 \%$ of households report internet access; and merely 99,000 people have registered broadband subscriptions (ITU, 2018).

These relatively low penetration rates stand in contrast to Cuba's provision of advanced technological training including degrees in Telecommunications Engineering (since 1985) and Computational Science (since 1991) offered by the Technological University of 
Havana José Antonio Echeverría. Significantly, these educational policies support the nation's commitment to egalitarian education. However, despite having one of the highest literacy rates in Latin America, Cuba's technical training has not translated into equally strong levels of internet penetration or use.

This may lie in regulations on telecommunications. Regulations issued by the Ministry of Communications have limited infrastructure (Recio, 2013). Illustrative examples include: the Decree 209/96 (access to global computer networks will prioritize national interests, legal entities, and institutions of greater relevance to the country's development); the Resolution 90/00 (interconnection between national users will be carried out only through national means of transmission, which avoids the costs of international companies but also ensures mechanisms for monitoring content); and the Resolution 197/2013 (public internet access service "Nauta" will be implemented, operated with prepaid cards that prohibits uses of the internet that may be considered harmful to public security, economy or sovereignty).

Not surprisingly, these policies and related limitations on use have resulted in under-utilization of ICTS. Even key sectors, such as education, have limited access ( $3 \%$ of school sites), thus compromising long-term quality of the service and creating lag in processes of digitalization, computerization, and software development. The local, collaborative encyclopedia EcuRed, for example, did not attempt to link to Wikipedia or other global initiatives but to develop its own platform (Recio, 2013). The Bolsa de Permutas, which sought to stimulate barters, failed in part because of the poor web quality and the preference of Cubans for platforms outside Cuba that had to be illegally accessed.

Some argue that these limitations contribute to slowed techno-informational development that allows the government to continue to control society (Kelly, Cook, \& Truong, 2012). Others argue that socio-political and economic changes are taking place in the country. However, they are not yet reflected in digital public spaces (Díaz Rodríguez \& Sokooh Valle, 2013), and that continuing to limit infrastructure and freedom of expression will continue to provoke friction in light of Cuba's high levels of educational attainment.

Top-down digital inclusion policies (Medellín Torres, 2004) are in conflict with the potential of the internet to empower society. An example of this is the recent use of internet-based portals to question Cuban authorities regarding their reaction to the COVID-19 outbreak. According to Baró (2020), there were more than 6,000 comments on the official portal Cubadebate to request stricter measures, including the suspension of classes, ultimately decreed by the government. In sum, Cuba provides a provocative example of lag between the potential of a highly literate civil society and a government whose policies fluctuate between meeting people's demands and keeping them under control for political and ideological reasons.

\section{Digital Inclusion in Jamaica}

Jamaica is the largest of the independent Anglophone Caribbean countries, with an estimated population of 2.9 million (World Bank, 2019). Liberalization of the telecommunication sector occurred in 1993 with policies developed by the Technology Ministry. Jamaica's strategic plan, ICT Vision 2030, articulates key benchmarks including expanded ICT infrastructure, steady development of human resources through systematic training, promotion of widespread information literacy in education and the general population, employment creation, and building of an enabling environment for ICT research and innovation.

Jamaica's $67.4 \%$ internet penetration ranked 7 th in 2019 among other Caribbean countries (see Figure 2). However, a large proportion of this access was via mobile devices in a region with more mobile phone handsets than people. The country's small stock of internet-ready households remains a challenge. According to government data, Jamaica had a relatively low level of domestic 'postpaid' broadband subscriptions, amounting to 1.7 per 100 persons, compared to 2.95 per 100 persons in the wider Caribbean region in 2018 (Ministry of Science, Energy and Technology, 2018). These households with broadband access were predominantly in more affluent neighborhoods.

The performance of the ICT sector in Jamaica (67.4\%) is better than or on par with global trends for similar developing countries. Figures from Internet World Stats for March 2020 indicated a world average internet penetration of $58.7 \%$, where Africa, for example, was at $39.3 \%$ penetration. The access policies that have been pursued by the Jamaican government towards attaining its development goals include establishing community internet access points, free community Wi-Fi at designated hotspots, programs providing free laptop computers in schools, as well as dedicated formal training programs in ICT skills. Approximately $18 \%$ of persons enrolled in training programs at the government's HEART Trust National Training Agency, for example, were pursuing ICT related courses, including internet programming, web design, and computer repairs and maintenance (Jamaica Government, 2007).

Some of these community-based programs and government-driven measures to increase access were financed through a Universal Service Fund established in 2005. A levy was imposed by the Jamaican government on incoming overseas telephone calls to provide funds intended to support underserved local communities. Legal challenges by external providers to the legitimacy of the levy did not succeed, and Fund resources accumulated to significant levels that at times were under-utilized. The advent of free internet-based international calling has significantly reduced the annual income from the levy. At the same time, the available research indicates that some vulnerable population segments remained underserved in Jamaica's ICT coverage, including residents of 


\begin{tabular}{|c|c|c|c|}
\hline Country & Penetration \% & Population 2019 & $\begin{array}{l}\text { GDP US\$ per } \\
\text { Capita }\end{array}$ \\
\hline Curacao & 93.1 & 149,000 & 15,000 \\
\hline Antigua and Barbuda & 87 & 94,000 & 27,542 \\
\hline Puerto Rico & 85.2 & $3.6 \mathrm{~m}$ & 27,400 \\
\hline Bahamas & 84 & 392,000 & 33,516 \\
\hline Trinidad and Tobago & 77.2 & $1.2 \mathrm{~m}$ & 33,026 \\
\hline Barbados & 78 & 291,000 & 18,866 \\
\hline Jamaica* & 67.4 & $2.9 \mathrm{~m}$ & 9,726 \\
\hline St Lucia & 66.5 & 165,000 & 15,225 \\
\hline Dom. Rep. & 57.1 & $10.6 \mathrm{~m}$ & 19,435 \\
\hline Haiti & 12.9 & $10.2 \mathrm{~m}$ & 1,940 \\
\hline
\end{tabular}

Figure 2. Selected Caribbean countries: Percentage of internet penetration rates in 2019. Data from Dunn (2016), Internet World Stats (2020) and the ITU.

rural areas, residents in inner city communities, women business owners, and "unattached" youth (Dunn, 2016).

The advent of COVID-19 exposed the need for Caribbean countries like Jamaica to strengthen policies of social inclusion and effective access. Provisioning for disaster preparedness, emergencies, and environmental crises is to be found in the country's 2005 Natural Hazard Risk Reduction Policy and the more recent 2015 Disaster Risk Management Act. The country's Vision 2030 Development Plan also speaks to improving national disaster mitigation, decreasing risk vulnerabilities, and enhancing adaptation. Yet, these documents disclosed that there was little or no anticipation of a pervasive health crisis as posed in 2020 by COVID-19.

Internet access through mobile phones did not prove a suitable platform in the COVID-19 crisis. Administrations, as well as service providers, must move more swiftly to improve household internet penetration and public Wi-Fi access levels. For example, calls by government and university authorities asking for an urgent resort to online delivery of classes were not fulfilled. Schools collaborated more successfully with traditional media outlets such as radio and television to deliver classes to students at home. But even this more accessible mode of delivery did not prove suitable for some, given variable domestic circumstances and the need for some parents and caregivers to prioritize earning a living. Inadequate prior training of staff, wide variation in internet access by students, associated high costs, and often unsuitable domestic circumstances for such classes all pose significant challenges to digitizing education.

\section{Digital Inclusion in the United States}

The Silicon Valley in California is one of the last places on earth you would expect to find significant and persistent digital inequality; yet, nearly 100,000 residents of the City of San Jose lack meaningful internet access, as do nearly $25 \%$ of Californians overall (Levine, 2018). Looking at this epicenter tells us much about digital inequalities in locations with great wealth disparity, as is increasingly the case in California.

In the United States., home broadband adoption increased steadily from 2002 to 2010. In 2010 it plateaued at approximately $70 \%$, and as of the most recent survey is at 73\% (Pew Research Center for Internet \& Technology, 2019). Further, when looking at digital inequality by income level, we see low-income households comprise the biggest portion of the disconnected. To date, efforts to address this gap have primarily involved third-party, community-based organizations attempting to identify and connect low-income households to existing, affordable offers and have yielded poor results (Hauge \& Prieger, 2015; Manlove \& Whitacre, 2019).

Economic data from a pilot project in San Diego provides an important understanding of the challenges. Of the respondents, $90.15 \%$ had an annual household income of less than $\$ 30,000$, and $71.12 \%$ had an annual household income of less than $\$ 20,000$. Combined, three different California projects with over 100,000 participants tested a number of out-reach methods to lowincome households to raise awareness of existing, affordable offers, assist with obtaining free/low-cost devices, 
and provide enrollment in free digital literacy classes. Of the three projects, the highest broadband adoption rate was $1.21 \%$.

Cost is the biggest impediment to closing the gap, as we see with other cases such as Canada. Voluntary and/or community-based programs are not working. As such, mandated outreach and assistance policies and programs targeting low-income households should be implemented as they have been for electricity, telephony, natural gas, water, and other necessary utilities. These programs are overseen by the government entities and operated by the utilities. The programs have enrollment targets, require outreach efforts, and contain reporting requirements.

Also, like other cases, there is a second, completely different cause: the lack of infrastructure necessary to reach rural areas. According to the California Public Utilities Commission (CPUC) 2018 CASF Annual Report, $98.7 \%$ of non-rural California households have access to broadband infrastructure allowing service offerings of $10 / 1 \mathrm{Mbps}$, while only $71.5 \%$ of rural households have access to that infrastructure (CPUC, 2019). Because of the disparity in population bases, rural, disconnected households account for $4.78 \%$ of the gap (Levine, 2018).

Connecting rural areas requires laying many miles of cable to bridge the gap between the internet backbone and the rural communities. The trenching necessaryover great distances and often through very challenging terrain -is very expensive, and rural communities frequently lack sufficient end-user density, meaning that companies would likely never see the returns necessary to cover the cost of deployment. Here too, the power of government is necessary to address digital inequality. Investment from modern versions of the Rural Electrification Act, such as CASF and the Connect America Funds, are needed to make sure rural residents are afforded the same opportunities to reap the benefits of internet enabled technological benefits.

Further, the pandemic caused by the Coronavirus has brought into sharp focus the depth and profound consequences of these digital inequalities. Based upon early observations, the consequences of the pandemic have been most glaringly apparent in the efforts of school districts to change from traditional to distance learning as most schools and school districts in California have remained closed since 16 March. Without any concerted state-wide policy, public schools have floundered and been unable to provide equal access to digital learning, thus failing their mission to provide an education for all. Clearly, even in Silicon Valley and the rest of California, without government leadership and intervention, educational, as well as urban and rural digital inequalities will persist.

\section{Digital Inclusion in Canada}

In Canada, digital inequality persists in many rural communities, while users in urban and rural settings alike re- port prohibitive pricing and lack of appropriate digital literacy programming. The need for nation-wide affordable access and digital-skills initiatives has been confirmed from 2001 (National Broadband Task Force) to 2006 (Canadian Telecommunications Policy Review Panel) to 2018 (Auditor General of Canada).

In 2016 the national regulator, the Canadian RadioTelevision and Telecommunications Commission (CRTC), established a new Basic Service Objective recommending speeds of $50 \mathrm{Mbps}$ download/10Mbps upload. This decision resulted from long-term advocacy by Indigenous and public interest groups in CRTC proceedings, including 2012 hearings on Northwestel's Modernization Plan and a 2014 inquiry on satellite services. The CRTC has also stepped in to re-regulate retail rates in Northern Regions that lack competition and announced a consumer-oriented internet code. Government has also set up several broadband funding programs managed by Innovation, Science and Economic Development Canada (ISED), the CRTC, and a forthcoming Universal Service Fund (ISED, 2019). These funds have already contributed to major projects including the Mackenzie Valley Fibre Link in the Northwest Territories, the Dempster Fibre Project in the Yukon, and funding for satellite infrastructure in Nunavut.

Nonetheless, additional public investments in broadband infrastructure and digital literacy initiatives in rural and Indigenous regions are needed. Community advocates have raised concerns about adequate infrastructure and services, as well as reliance on commercial providers rather than non-profit and cooperative organizations controlled by affected communities. Community advocates, many led by Indigenous peoples, continue to push for the co-development initiatives to address the specific contexts of user groups and promote local ownership and control of digital inclusion initiatives.

With respect to digital literacy, interventions should reflect the specific characteristics of user communities. Initiatives like the ISED funded Digital Literacy Exchange Program provided seed funding to deliver appropriate digital literacy initiatives to aid users to monitor speed and quality of service, ensure fair pricing practices, and protect against online risks. One example of such an effort combines digital literacy with efforts to document the rich cultural teachings of Elders from the Piikani Blackfoot Nation in southern Alberta (Jordan, 2018). In the Piikani Nation, a strong desire to document and share culture and language using ICTs is tempered by limited access, high-costs services, and concern over the negative impacts of adoption. Through an ongoing participatory action research project, Piikani Elders work with university-based researchers to collaboratively shape digital literacy workshops and learning resources that support their cultural revitalization goals. This approach stresses how important it is to learn from communities about how best to tailor digital literacy programming to mitigate risks and harness the potential of digital ICT. 
It is important that digital inclusion efforts highlight the efforts of diverse user communities who have a long history of technology innovation (McMahon, Hudson, \& Fabian, 2017). Countering the top-down approach of technology transfer, these communities have led local and regional networking initiatives since the early days of the internet (Carpenter, 2010; O'Donnell et al., 2016). This reflects a first-mile orientation towards endogenously driven telecommunications development (Paisley \& Richardson, 1998) from Fort Severn's networks in Ontario to complex regional systems such as Tamaani Internet in Nunavik (First Mile Connectivity Consortium, 2018). The Kuhkenah Network began connecting communities in 1994 and has since scaled up to support regional networks and broadband-enabled applications such as ehealth and online education. Such projects demonstrate infrastructure deployment in expensive-to-serve areas while retaining community ownership and control of networks, services, and applications. Their diversity illustrates a key point: Digital inclusion policy and programming must engage and reflect social practices that will drive effective use in a variety of community settings (Gurstein, 2012).

Discrepancies in access have been highlighted during the COVID-19 pandemic, as public services and businesses scramble to move online, putting increased strain on already-burdened networks in rural, remote, and Northern Regions of the country. In these regions, people are even more reliant on accessible, affordable connectivity services since many small villages lack brick-andmortar health centers, schools, shops, and other organizations. Due to travel restrictions, the limited availability of local technicians constrains the ability of telecommunications companies to fix broken networks, which bolsters arguments to increase local ownership and capacity for community networks. Furthermore, as more people move their activities online, vulnerable groups are being increasingly targeted by online scams and misinfor- mation, further highlighting the importance of digital literacy (Daigle, 2020). While some commercial providers are waiving fees at least temporarily (Northwestel, 2020), the policies of commercial internet service providers, such as the imposition of data caps, are exacerbated as more services and activities move online. For all of these reasons, the challenges of COVID-19 further underscore the urgency of meeting the needs of digitally marginalized groups.

\section{Paths Forward}

These case studies offer food for thought for future research and policy efforts. Nationally scaled digital inclusion programs are especially viable in smaller populations with higher levels of education, stable political environments, and governmental strata that work together. It is smaller populations where we have seen the greatest increases in internet adoption over the last 10 years (Figure 3). As the case of Uruguay demonstrates, digital inclusion policies succeed when they have backing from the executive branch, support from across the political spectrum, and integration of local stakeholders. They also succeed when they provide devices and access, as well as free and locally developed digital services and opportunities for skill development as exemplified by the Plan Ceibal and Plan Ibirapitá.

However, we also must add that a strong government is not always the answer. The Cuban case illustrates the shortcomings of top-down policies in a context of reduced freedom. The Cuban case offers important insight into the effects of limited freedom of speech and digital inclusion. The Cuban case also points to the need to think of digital inclusion beyond the legal frameworks and the formalities of regulations. While Cuba has been a pioneer in developing such frameworks, these regulations were implemented by an authoritarian regime such that ordinary people do not benefit from ICTs. Moreover,

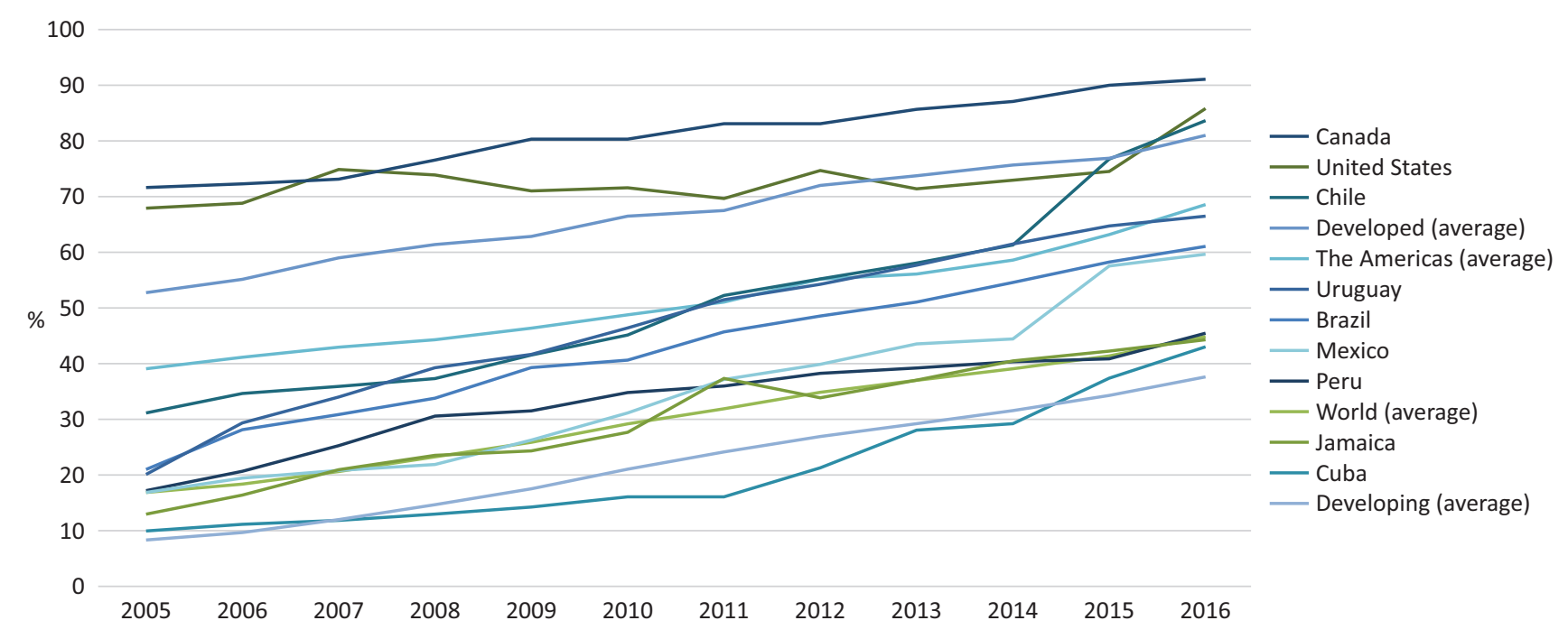

Figure 3. Individuals using the internet (percentages), 2005-2016. Assembled by author Matias Dodel with data from ITU (2019b). 
Cuba underscores the connection between the absorption capacity of civil society (e.g., education) to receive new technologies that, intended or not, may challenge current trends in government and politics. Finally, the Cuban case shows that digital inclusion is connected to a society's capacity to appropriate technological developments, appropriation that is optimized when high levels of education provide opportunities to capitalize on the opportunities opened by ICTs.

In addition to public policy, stakeholders must have input. In Mexico, Brazil, and Canada, Indigenous and rural community groups have worked together to drive digital development initiatives in ways that meet their selfdetermined interests. Through a range of deployment initiatives, these groups are setting up and operating digital infrastructure, services, and applications. This work extends to recent efforts to develop and deliver appropriate digital literacy programs. Many of these projects adopt a non-profit or cooperative organization model, which enables community networking while addressing the challenges of market failure. In Canada, through national initiatives such as the First Mile Connectivity Consortium (www.FirstMile.ca) and in forums including the annual Indigenous Connectivity Summit, these groups are collaborating with like-minded organizations and individuals across the Americas (McMahon, 2020). With respect to digital inclusion policy development and the creation of culturally appropriate digital literacy resources, this kind of strong ethos of sharing and cooperation is central to the success of knowledge exchange across low-resourced environments. Finally, insights from the Canadian case are also present in programs in Mexico such as REDES A.C. and Rhizomática, which also reflect this approach and participated in the Indigenous Connectivity Summit (Magallanes-Blanco \& RodriguezMedina, 2016) and Leal's work with Indigenous communities in the state of Roraíma in Brazil (Leal \& Brant, 2012). Therefore, the pandemic underscores arguments to increase local ownership and capacity of community networks, particularly in rural and remote regions, and recognizes the essential role that Indigenous and nonprofit telecom providers-as well as commercial service providers-play in these communities.

Future work must also consider digital inclusion as permeated by legal issues (e.g., patents, copyrights) and economic asymmetries (e.g., access to cutting-edge ICTs) given the great disparities in the development of technologies across different national cases. Scholars must also seek to identify links between different welfare state regimes and digital inclusion policy strategies (i.e., market driven, state founded, a combination) to see the potential for NGOs to provide solutions. Finally, future work must reveal the importance of supporting on-the-ground initiatives that are driven by locally situated groups, such as community networking initiatives and efforts to codevelop and share appropriate digital literacy resources. Often these initiatives are organized around a non-profit or cooperative model, which helps address the limita- tions of market-driven and state-founded initiatives in ru$\mathrm{ral} /$ remote regions.

\section{Implications of the COVID-19 Pandemic: A New Frontier for Digital Inclusion}

At the time of writing, we are in the early stages of the COVID-19 pandemic. Yet already we see the widening gap between the digital haves and have-nots that is dramatically amplified by this global health crisis. As the months of pandemic unfold, we will no doubt see governments across the Americas and the Caribbean begin to grapple with emergent policy to better connect the digitally disenfranchised.

Until they do so effectively, however, the digitally disadvantaged will be de facto excluded from potentially life-saving resources including access to public health information, time-sensitive governmental directives, and telemedicine. Those without quality access to digital resources and the skills to use them cannot avail themselves of critical digital resources--this new gap will have profound implications for all life realms. Those without digital resources will be at greater risk for exposure to the virus as they must acquire food and medication in person because they cannot avail themselves of online shopping and digital delivery services that allow the digitally resourced to better self-isolate and shelter in place.

In addition to very real health and safety risks, there are long-term ripple effects from the virus for the digitally disadvantaged that will wreak hardship to a degree that we cannot yet imagine in these early stages of the age of COVID-19. Financially, while the digitally advantaged telecommute, work from home, and zoom together, those who cannot telecommute may lose their jobs, suffer insurmountable financial devastation, and helplessly witness any fingernail hold on economic well-being evaporate due to mounting bills and diminished income. The economic devastation unleashed by the COVID-19 pandemic will also have long-term impact in the workforce in terms of job-loss divides (Equipos Mori, 2020). For those far from family and physically distant from support networks, the emotional ramifications of these blows will also be suffered in social isolation while locked down at home. Emotionally, the digitally disadvantaged will also suffer the effects of social isolation to a much greater degree than their resourced counterparts who can better maintain contact with family, loved ones, and social networks on a variety of digital platforms, apps, and devices.

This will also hold true for children whose schooling and educational socialization have been abruptly curtailed to stop the spread of the virus. While some schools and educators scramble to provide distance learning and e-education, even their best efforts will not be enough unless students benefit from coordinated and large-scale programs like Ceibal in Uruguay. Without such programs, those children who lose months of formal education and who lack digital resources will likely fall behind their resourced peers who can turn to e-education resources, 
connectivity, devices, and skills-learning at home. These educational disruptions may create generational lags with lifelong effects.

In closing, the propagation of the COVID-19 pandemic across the Americas and the Caribbean exposes the different degrees of social and digital fragmentation within this region. Simultaneously, the crisis reinforces the need for rapid-response and long-term policy solutions to guarantee the right of access to the internet for all to meet every social, educational, work, and health need. Future research must explore these new frontiers in digital inclusion, but now-more than ever-we need digital inclusion for all the world's population as society is being radically transformed by the COVID-19 pandemic.

\section{Acknowledgments}

The authors wish to extend our appreciation to volume editors Bianca C. Reisdorf and Colin Rhinesmith for their exemplary editorial work, as well as to the reviewers for their helpful suggestions. In particular we thank Mariana Pires for her invaluable shepherding of the manuscript and generosity of time and spirit. Finally, we thank the journal Social Inclusion for the opportunity to share our work thanks to their much-appreciated provision of open access publishing. In addition, the Chilean author wishes to thank the following grant: Fondecyt 1170324. The Uruguayan author wishes to thank the following grant: ANII FCE_3_2018_1_149415. The Canadian author wishes to thank the Social Science and Humanities Research Council of Canada (grant 435-2018-0596) and the Internet Society's Beyond the Net grant program.

Please note that the order of authors reflects lead authorship of the sections as follows: Laura Robinson and Jeremy Schulz (Digital Inclusion Across the Americas and Caribbean in Times of Pandemic), Matias Dodel (Digital Inclusion in Uruguay), Teresa Correa (Digital Inclusion in Chile), Eduardo Villanueva-Mansilla (Digital Inclusion in Peru), Sayonara Leal (Digital Inclusion in Brazil), Claudia Magallanes-Blanco (Digital Inclusion in Mexico), Leandro Rodriguez-Medina (Digital Inclusion in Cuba), Hopeton S. Dunn (Digital Inclusion in Jamaica), Lloyd Levine (Digital Inclusion in the USA), Rob McMahon (Digital Inclusion in Canada), Aneka Khilnani (Paths Forward), and Jeremy Schulz and Laura Robinson (Implications of the COVID-19 Pandemic: A New Frontier for Digital Inclusion). Finally, as corresponding author, Jeremy Schulz was responsible for manuscript submission and coordination on behalf of co-authors.

\section{Conflict of Interests}

The authors declare no conflict of interests.

\section{References}

Baca-Feldman, C., Bloom, P., Gómez, M., \& Huerta, E. (2018). Global information society watch 2018.
Community networks. Association for Progressive Communications. Retrieved from https://www.apc. org/en/pubs/global-information-society-watch2018-community-networks

Baró, M. (2020, 30 March). Cierre de escuelas: El costo social de estar aislados [Closing schools: the cost of isolation]. Periodismo De Barrio. Retrieved from https://www.periodismodebarrio.org/2020/03/ cierre-de-escuelas-el-costo-social-de-estar-aislados

Bisset Álvarez, E., Grossi de Carvalho, A. M., \& Vidotti, A. B. G. (2015). Políticas públicas de inclusión digital: El caso de América Latina y Cuba [Public policies on digital inclusión: The case of America Latina and Cuba]. Biblios: Journal of Librarianship and Information Science, 58, 42-53.

Brazilian Institute of Geography and Statistics. (2018). Síntese de indicadores sociais: Uma análise das condições de vida da população brasileira [Synthesis of social indicators: An analysis of living conditions for Brazil's population]. Rio de Janeiro: Brazilian Institute of Geography and Statistics. Retrieved from https://biblioteca.ibge.gov.br/visualizacao/livros/ liv101629.pdf

Brazilian Internet Steering Committee. (2019). TIC Domicílios: Pesquisa sobre o uso das tecnologias de informação e comunicação nos domicílios Brasileiros [ICT household survey on the use of information and communication technologies in Brazilian households]. São Paulo: Brazilian Internet Steering Committee. Retrieved from https://www.cetic.br/ media/docs/publicacoes/2/12225320191028-tic_ dom_2018_livro_eletronico.pdf

California Public Utilities Commission. (2019). 2018 annual report California advanced services fund. San Francisco, CA: California Public Utilities Commission. Retrieved from https://www.cpuc.ca.gov/ uploadedFiles/CPUCWebsite/Content/About_Us/ Organization/Divisions/Office_of_Governmental_ Affairs/Legislation/2019/CASF\%202018\%20Annual\% 20Report\%20April\%202019.pdf

Carpenter, P. (2010). The Kuhkenah network (K-Net). In J. P. White, J. Peters, D. Beavon, \& P. Dinsdale (Eds.), Aboriginal policy research VI: Learning, technology and traditions. Toronto: Thompson Educational Publishing.

Clastornik, J., Dornel, S., \& Parra, D. (2016). Uruguay's digital policy. In J. Bertot, E. Estevez, \& S. Mellouli (Eds.), Proceedings of the 9th international conference on theory and practice of electronic governance. New York, NY: ACM.

Correa, T., Pavez, I., \& Contreras, J. (2017). Beyond access: A relational and resource-based model of household Internet adoption in isolated communities. Telecommunications Policy, 41(9), 757-768.

Correa, T., Pavez, I., \& Contreras, J. (2018). Digital inclusion through mobile phones? A comparison between mobile-only and computer users in internet access, skills and use. Information, Communication \& Society. 
Díaz Rodríguez, E., \& Sokooh Valle, F. (2013). Internet y las TIC en Cuba: Notas para un debate sobre políticas públicas [Internet and ICTs in Cuba: Notes for a debate on public policies]. Temas, April/June(74), 62-67.

Dodel, M. (2015). Uruguay, sociedad e internet: Principales resultados de la encuesta WIP+UY 2013 [Uruguay, society and internet: Key findings of the WIP+UY 2013 survey]. Montevideo: Catholic University of Uruguay.

Dodel, M., Kweksilber, C., Aguirre, F., \& Méndez, I. (2018). Informe kids online Uruguay: Niños, niñas y adolescentes conectados [Kids online Uruguay report: Connected kids and adolescents]. Montevideo: Global Kids Online, UNICEF.

Dunn, H. (2016). ICT Indicators survey. Kingston: CARIMAC, Office of Utilities Regulation and the University of the West Indies.

Elizalde, R. M., \& Lagarde, M. H. (2013, May 29). Internet en Cuba: 'No será el mercado quien regule el acceso al conocimiento' [Internet in Cuba: The market will not regulate knowledge]. Cubadebate. Retrieved from http://www.cubadebate.cu/noticias/2013/ 05/29/no-publicar-Internet-en-cuba-no-sera-elmercado-quien-regule-el-acceso-al-conocimiento

Equipos Mori. (2020). El mundo del trabajo no perdona [The world of labor is not forgiving]. Equipos Mori. Retrieved from https://equipos.com.uy/el-mundo-deltrabajo-no-perdona

First Mile Connectivity Consortium. (2018). Stories from the First Mile: Digital technologies in remote and rural Indigenous communities. Fredericton: FMCC.

Galperín, H. (2017). Sociedad digital: Brechas y retos para la inclusión digital en América Latina y el Caribe [Digital society: Divides and challenges for digital inclusion in Latin America and the Caribbean]. Montevideo: UNESCO Office Montevideo and Regional Bureau for Science in Latin America and the Caribbean. Retrieved from http://www.unesco.org/new/ fileadmin/MULTIMEDIA/FIELD/Montevideo/pdf/ PolicyPapers-ConfMinistros-BrechaDigital-ES.pdf

García Requena, R. (2018, September 18). La importancia de fomentar la inclusión digital en México [The relevance of fostering digital inclusion in Mexico]. $L a$ Razón. Retrieved from https://www.razon.com.mx/ columnas/la-importancia-de-fomentar-la-inclusiondigital-en-mexico

Gurstein, M. (2012). Toward a conceptual framework for a community informatics. In A. Clement, M. Gurstein, G. Longford, M. Moll, \& L.R. Shade (Eds.), Connecting Canadians: Investigations in community informatics (pp. 35-60). Edmonton: AU Press.

Hauge, J. A., \& Prieger, J. E. (2015). Evaluating the impact of the American recovery and reinvestment Act's BTOP broadband adoption. Applied Economics, 47(60), 6553-6579.

Instituto Nacional de Estadística, Geografía e Informática. (2018). Encuesta nacional sobre disponibilidad y uso de tecnologías de la información en los hogares [National pool on availability and uses of information technologies at households]. Instituto Nacional de Estadística, Geografía e Informática. Retrieved from https://www.inegi.org.mx/programas/dutih/2018

Innovation, Science and Economic Development Canada. (2019). High-speed access for all: Canada's connectivity strategy. Ottawa: Government of Canada. Retrieved from https://www.ic.gc.ca/eic/site/139.nsf/ eng/h_00002.html

International Telecommunications Union. (2018). Measuring the information society report. Geneva: ITU Publications. Retrieved from https://www.itu.int/ en/ITU-D/Statistics/Documents/publications/ misr2018/MISR-2018-Vol-2-E.pdf

International Telecommunications Union. (2019a). Core household indicators. Retrieved from https:// www.itu.int/en/ITU-D/Statistics/Documents/ statistics/2019/CoreHouseholdIndicators.xIsx

International Telecommunications Union. (2019b). Percentage of Individuals using the Internet. Data file. International Telecommunications Union. Retrieved from https://www.itu.int/en/ITU-D/Statistics/ Documents/statistics/2019/Individuals_Internet_ 2000-2018_Dec2019.xls

Internet World Stats. (2020). World internet usage. Internet World Stats. Retrieved from https://www. internetworldstats.com/stats.htm

Jamaica Government. (2007). Vision 2030 Jamaica: Information and communications technology (ICT) sector plan. Kingston: Jamaica Government. Retrieved from https://planipolis.iiep.unesco.org/sites/planipolis/ files/ressources/jamaica_draft_ict_sector_plan.pdf

Jordan, K. (2018). The Piikani cultural and digital literacy camp program. Internet Society. Retrieved from https://www.internetsociety.org/blog/2018/ 05/the-piikani-cultural-and-digital-literacy-campprogram

Kelly, S., Cook, S. G., \& Truong, M. (2012). Freedom on the net 2012: A global assessment of internet and digital media. Washington, DC: Freedom House.

Kleine, D. (2013). Technologies of choice? ICTS, development, and the capabilities approach. Cambridge, MA: MIT Press.

Leal, S., \& Brant, S. (2012). Políticas de inclusão digital no Brasil: A experiência da formação dos monitores dos telecentros GESAC [Digital inclusion policies in Brazil: Experiences training instructors for GESAC telecenters]. Liinc em Revista, 8(1).

Levine, L. (2018). Closing the digital divide: A justification for government intervention. Bingley: Emerald Group Publishing.

Ludeña, P., Martínez, A., \& Rendon, A. (2011). Tecnologías de la información y las comunicaciones para zonas rurales: Aplicación a la atención de salud en los países en desarrollo [Information and communication technologies for rural areas: Application to healthcare in developing countries]. Madrid: CYTED. 
Magallanes-Blanco, C., \& Rodriguez-Medina, L. (2016). Give me a mobile and I will raise a community. In L. Robinson, J. Schulz, \& H. S. Dunn (Eds), Digital empowerment: Opportunities and challenges of inclusion in Latin America and the Caribbean. Bingley: Emerald Group Publishing.

Manlove, J., \& Whitacre, B. (2019). An evaluation of the connected nation broadband adoption program. Telecommunications Policy, 43(7).

McMahon, R., the First Mile Connectivity Consortium, \& the Piikani Cultural and Digital Literacy Camp Project Team. (2020). Co-developing digital inclusion policy and programming with Indigenous partners: Interventions from Canada. Internet Policy Review, 9(2).

McMahon, R., Hudson, H. E., \& Fabian, L. (2017). Canada's Northern communication policies: The role of Aboriginal organizations. In N. J. Mulé \& G. C. DeSanti (Eds), The shifting terrain: Public policy advocacy in Canada (pp. 259-292). Montreal: McGillQueen's University Press.

Medellín Torres, P. (2004). La política de las políticas públicas: Propuesta teórica y metodológica para el estudio de las políticas públicas en países de frágil institucionalidad [The politics of public policies: Theoretical and methodological proposal for the study of public policies in countries with fragile institutions]. Santiago de Chile: United Nations-ECLAC.

Ministry of Health. (2020). Ministério da saúde disponibiliza aplicativo sobre o Coronavírus [Ministry of Health Provides Response to the Coronavirus]. UNA-SUS. Retrieved from https://www.unasus.gov.br/noticia/ ministerio-da-saude-disponibiliza-aplicativo-sobreo-coronavirus

Ministry of Science, Energy and Technology. (2018). Vision 2030 Jamaica. Information and communication technology (ICT) sector plan 2009-2030 (Final Draft Report). Kingston: Government of Jamaica. Retrieved from https://www.mset.gov.jm/wp-content/ uploads/2019/09/ICT-Sector-Plan-Complete.pdf

Napoli, P. M., \& Obar, J. A. (2014). The emerging mobile Internet underclass: A critique of mobile Internet access, The Information Society, 30(5).

Nathan, M., Pardo, I., \& Cabella, W. (2016). Diverging patterns of fertility decline in Uruguay. Demographic Research, 34, 563-586.

National Telecommunications Agency. (2020). Medidas a serem adotadas pelo setor de telecomunicações diante da disseminação da COVID-19 [Measures to be taken by the telecommunications sector in response to the spread of COVID-19]. Direito da Comunicação. Retrieved from https://direitodacomunicacao.com/ telecomunicacoes/medidas-a-serem-adotadaspelo-setor-de-telecomunicacoes-diante-dadisseminacao-da-covid-19

Northwestel. (2020). Northwestel's update on COVID-19. Northwestel. Retrieved from https://www.nwtel.ca/ northwestels-update-covid-19-1

O’Donnell, S., Beaton, B., McMahon, R., Hudson, H. E.,
Williams, D., \& Whiteduck, T. (2016). Digital technology adoption in remote and northern Indigenous communities in Canada: An overview. Paper presented at the Canadian Sociological Association 2016 Annual Conference, University of Calgary, Calgary, Alberta.

Paisley, L., \& Richardson, D. (1998). Why the first mile and not the last. The first mile of connectivity. Rome: Communication for Development Rome, Food and Agriculture Organization of the United Nations (FAO).

Pew Research Center for Internet \& Technology. (2019). 2019 internet broadband fact sheet. Pew Internet. Retrieved from https://www.pewinternet.org/factsheet/internet-broadband

Plan Ceibal. (2017). 10 años Plan Ceibal: Hicimos historia haciendo futuro [Plan Ceibal 10 years: We made history building future]. Montevideo: Plan Ceibal. Retrieved from https://www.ceibal.edu.uy/storage/ app/media/documentos/ceibal-10-2.pdf

Plan Ceibal. (2020). Recursos de Plan Ceibal ante llegada de coronavirus a Uruguay [Plan Ceibal resources in the face of the arrival of coronaviruses in Uruguay]. Ceibal. Retrieved from https://www.ceibal. edu.uy/es/articulo/recursos-de-plan-ceibal-antellegada-de-coronavirus-uruguay

Plan Ibirapitá. (2017). Memoria 2017 [Annual report 2017]. Ibirapitá. Retrieved from http://ibirapita.org. uy/wp-content/uploads/2018/04/plan_ibirapita_ MEMORIA-2017.pdf

Prieto-Egido, I., Simó-Reigadas, J., Liñán-Benítez, L., García-Giganto, V., \& Martínez-Fernández, A. (2014). Telemedicine networks of EHAS foundation in Latin America. Frontiers in Public Health, 15.

Recio, M. (2013). La hora de los desconectados. Evaluación del diseño de política de 'acceso social' a Internet en Cuba en un contexto de cambios [The time of the disconnected. Evaluation of the policy design of 'social access' to the internet in Cuba in a context of change]. Buenos Aires: Latin American Council for Social Sciences/CLACSO. Retrieved from http://biblioteca.clacso.edu.ar/clacso/becas/ 20131219083409/Recio_trabajo_final.pdf

Rey-Moreno, C., Bebea-Gonzalez, I., Foche-Perez, I., Quispe-Tacas, R., Liñán-Benitez, L., \& Simo-Reigadas, J. (2011). A telemedicine WiFi network optimized for long distances in the Amazonian jungle of Peru. In ExtremeCom '11: Proceedings of the 3rd Extreme Conference on Communication: The Amazon Expedition. New York, NY: Association for Computing Machinery. https://doi.org/10.1145/2414393.2414402

Rosas, E., \& Ovando, C. (2018). Inclusión digital en México, el reto de consolidar un derecho entre los adultos mayores [Digital inclusion in Mexico, the challenge of consolidating a right among older adults]. Sociedades y Desigualdades, 6, 48-80.

Sharma, A., \& Lucini, B. A. (2016). Inclusión digital en América Latina [Digital inclusión in Latin America]. London: GSM Association. Retrieved from 
https://www.gsma.com/latinamerica/connectedsociety/?lang=es

da Silva, M. A. R. (2018). Inclusão digital nas escolas públicas: $O$ uso pedagógico dos computadores e o $P R O I N F O$ [Digital inclusion in public schools: The pedagogical use of computers and PROINFO]. Natal: EDUFRN.

Subsecretaría de Telecomunicaciones. (2019). Estudios [Studies]. Subtel. Retrieved from https://www. subtel.gob.cl/estudios/internet-y-sociedad-de-lainformacion

Sunkel, G., \& Ullmann, H. (2019). Older adults in the digital age in Latin America: Bridging the digital age divide. CEPAL Review, 2019, 215-236.

Tapscott, D. (2008). Growing up digital. Boston, MA: McGraw-Hill Education.

Trucco, D., \& Espejo, A. (2013). Principales determinantes de la integración de las TIC en el uso educativo: EI caso del Plan CEIBAL del Uruguay (No. 177) [Main determinants of the integration of ICT in educational use: The case of the CEIBAL Plan of Uruguay (No. 177)]. Santiago: United Nations Economic Commission for Latin America and the Caribbean.

United Nations. (2019). World population prospects. The 2019 revision. New York, NY: United Nations.

United Nations Development Program. (2016). 2016 human development report. New York, NY: United Nations Development Program. Retrieved from https://www.undp.org/content/dam/brazil/docs/ RelatoriosDesenvolvimento/undp-br-2016-humandevelopment-report-2017.pdf

World Bank. (2019). Jamaica population. World Bank Group. Retrieved from https://data.worldbank.org/ country/jamaica

\section{About the Authors}
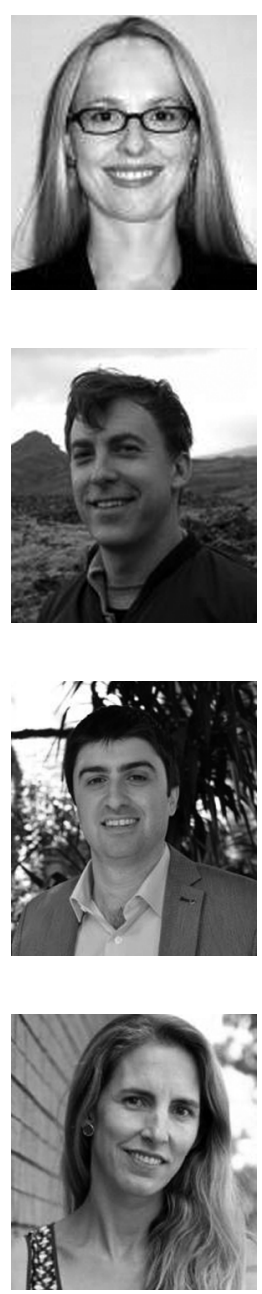

Jeremy Schulz is Researcher at the UC Berkeley Institute for the Study of Societal Issues and a Fellow at the Cambridge Institute. He has also served as an Affiliate at the UC San Diego Center for Research on Gender in the Professions and a Council Member of the ASA Section on Consumers and Consumption. Previously, he held an NSF funded postdoctoral fellowship at Cornell University after earning his PhD at UC Berkeley.

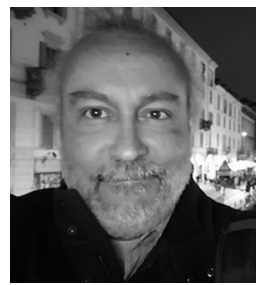

Matías Dodel holds a PhD from the Department of Sociology, University of Haifa. He is Associate Professor of Communications at Universidad Católica del Uruguay. He is the director of the Internet of People (IoP) research group, where he coordinates the Uruguayan chapters of international comparative Internet studies such as World Internet Project, DiSTO (From Digital Skills to Tangible Outcomes), and Global Kids Online. His research interests are digital inequalities, social stratification, digital safety, and cybercrime.

Teresa Correa is Associate Professor in the School of Communication at Diego Portales University, Chile. Her research focuses on three lines of inquiry: digital inequality and the intersection of gender, class, race, rurality and family dynamics; media sociology and the representation of gender and minorities; and health communication, particularly media and household interactions about health-related decisions. Her research has been funded by the National Science and Technology Development Fund, and the International Development Research Centre from Canada.

Eduardo Villanueva-Mansilla is Professor in the Communications Department at the Pontifical Catholic University of Peru, as well as Head of Curricula and Studies of the School of Communications Sciences and Arts, Pontifical Catholic University of Peru. His interests are in the relationship between digital media and political transformations, with emphasis in communication policy; and ICTD. He is a member of the Consultative Board of the Latin American Communications Researchers Association (ALAIC). 

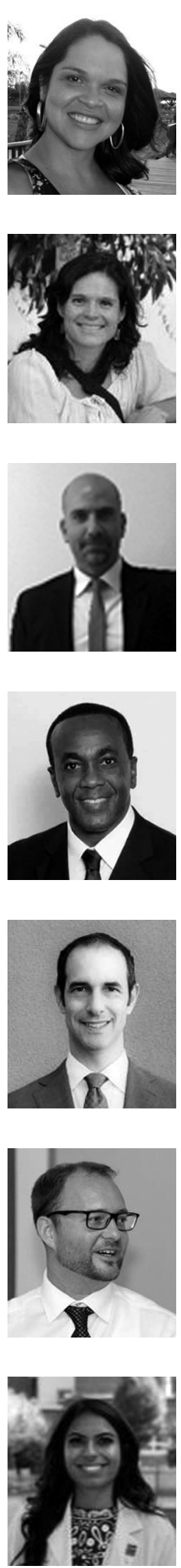

Sayonara Leal is Professor in the Department of Sociology at the University of Brasília (UnB-Brasil). She has a doctorate in Sociology (2007), a master's in Communication and Culture Policies at the Faculty of Communication at UnB (2001) and a master's degree in Social Change at the University of Lille from 2005. In 2013-2014, Sayonara Leal was in residence at the Center for Sociology of Innovation (CSI) at the École des Mines de Paris. Her research has several axes: education, science, technology, politics, values, and society. She is a member of the CLACSO Science and Society Working Group.

Claudia Magallanes-Blanco is Professor at the Ibero-American University Puebla, Mexico. For the past 20 years, Claudia has worked with Indigenous people in media and communications projects. She is coeditor of the Routledge book series Media and Communication Activism: The Empowerment Practices of Social Movements and co-author of chapter 13 "Media and Communications" of the International Panel on Social Progress. Her research focuses on indigenous communication, communication for social change, social movements, and the decolonization of research practices.

Leandro Rodriguez-Medina holds a PhD in Sociology from University of Cambridge and is Associate Professor of Political Science at the University of the Americas Puebla, Mexico. He is member of the Mexican System of Researchers (Level II, CONACYT) and Editor-in-Chief of Tapuya: Latin American Science, Technology and Society (Talor \& Francis) His research interests are social studies of science and technology, international circulation of academic knowledge, and the relationship between culture and city.

Hopeton S. Dunn is Professor of Media and Communication in the Department of Media Studies at the University of Botswana and Senior Research Associate in the School of Communication, University of Johannesburg, South Africa. Professor Dunn served as Director of the Caribbean School of Media and Communication at the University of the West Indies, Jamaica, where he remains Academic Director of the Mona ICT Policy Centre. He is a former Secretary General of the International Association for Media and Communication Research (IAMCR).

Lloyd Levine (Hon.) is a Senior Policy Fellow at UC Riverside's School of Public Policy and a former member of the California State Legislature. Levine served as Chair of the Assembly Committee on Utilities and Commerce, specializing in issues relating to electricity, renewable energy, telecommunications and broadband. He is the co-founder of the Center for Technology, Policy and Society at UC Riverside's School of Public Policy and a founding board member of the California Emerging Technology Fund.

Rob McMahon (PhD) is an Associate Professor at the University of Alberta, Canada. He worked as a postdoctoral researcher with the First Nations Innovation Project at the University of New Brunswick and co-founded the First Mile Connectivity Consortium, a national non-profit association of Indigenous technology organizations. His research focuses on the development, adoption, and use of broadband and internet technologies by rural, remote, Northern, and Indigenous communities.

Aneka Khilnani (MS) is currently a medical student at the George Washington University School of Medicine and Health Sciences in Washington, DC. She completed a master's degree in Physiology from Georgetown University, where she focused on preventative medicine and exploring novel renal pharmacologics. She has special interest in telemedicine and digital inclusion and has served on numerous editorial boards as Associate Editor including the American Behavioral Scientists and the Emerald Studies in Media and Communications. 